\title{
Pastorale sorg aan beswaardes en ongeduldiges met die oog op die opbou van die gemeente
}

PJ Rossouw

\begin{abstract}
Pastoral care for the objectors and the impatient: a church growth perspective

The aim of this article is to develop a pastoral theological perspective to a recent pastoral problem. This problem is the growing polarization within churches (with the focus on the Dutch Reformed Church) in South Africa today due to theological, church policy, social, economical and political factors. These factors are outlined and analysed systematically. Special attention is paid to the two poles - the objectors and the impatient. The "objector" is described as the church member who experiences an increasing concern and impasse with the church regarding new directions that are followed, and which are not correct according to his convictions and perceptions. The "impatient" is described as a church member who experiences an increasing impasse with the church because according to him the church is not going far enough in concretizing the full consequences of church policy (as spelled out in Church and Society for example). The nature, symptoms and needs of both are examined and guidelines fora directed pastoral care are proposed.
\end{abstract}

\section{Aannames}

Pastorale sorg aan beswaardes en ongeduldiges is ' $n$ onderwerp wat op drie aannames gebaseer is:

Die eerste aanname is die bestaan en identifiseerbaarheid van lidmate in die Ned. Geref. Kerk waarvan sommige as "beswaard" en ander as "ongeduldig" getipeer kan word. Die tweede aanname is dat die aard (en omvang) van die beswaardheid of ongeduld sodanig is dat dit ' $n$ teologiese besinning regverdig. Die derde aanname is dat die saak waaroor dit hier gaan, roep om 'n pastorale direktief, 'n pastorale strategie wat vanuit die Woord 'n pynlike diep chirurgiese ingreep op die situasie maak, dit analiseer en duidelike en prakties haalbare riglyne aan pastores deurgee vir sinduidende pastoraat in 'n tyd soos hierdie.

In die lig van hierdie aannames word drie sake vervolgens aan die orde gestel:

(i) Daar word 'n voëlvlug gegee oor die omvang van toekomsscenarios waarmee ons lidmate (ten regte of ten onregte, teen wil of dank) daagliks gekonfronteer word. (ii) In die lig van die inhoud van die saak waaroor dit vir beswaardes én ongeduldiges gaan, word (vanuit 'n pastorale hoek) die vraag na die verhouding tussen kerk en politiek van nader bekyk. (iii) Derdens word stilgestaan by die vraag na die toegespitste pastoraat aan beswaardes en ongeduldiges. 


\section{Toekomsscenario's as krisisbelewings}

Die huidige tydsgewrig word deur sommige beskryf as 'n oorgangstyd, ' $n$ tyd van transformasie, oftewel "interregnum", dit wil sê 'n tyd waarin die ou era byna verbygegaan het, maar die nuwe nog nie ingetree het nie. Die woorde verandering, aanpassing, onderhandeling, mag en magsdeling, partisie en integrasie, en "die nuwe Suid-Afrika", is so algemeen in gebruik dat mense dit nie eens meer hoor nie, verveeld, geïrriteerd, of (dalk hier en daar) opgewonde daaroor raak. Vanuit elke moontlike hoek word ons daagliks hiermee gebombardeer, gekonfronteer en geïndoktrineer.

En tog kan ons hierdie feit nie ignoreer nie. As lidmate Sondag in die kerkbanke sit of as hulle ons Maandagaand op huisbesoek tuis ontvang, is hulle nie net lidmate van die Ned. Geref. Kerk nie. Hulle vorm inderdaad deel van die gesprek oor verandering en aanpassing; die gesprek oor mag en magsdeling raak hulle lewens direk; hulle is deel van die plan vir die "Nuwe Suid-Afrika". Dit wat die Ned. Geref. Kerk sê of nie sê nie raak hulle lewens regstreeks; die standpunte van die kerk in Kerk en Samelewing raak hulle denke, gesindhede en daaglikse handel en wandel. Dit wat die leraar aan hulle oordra, staan dus nie ' $n$ millimeter los van die daaglikse nuusgebeure nie.

Juis daarom is dit so belangrik dat ons 'n greep sal hê op die dinge wat ' $n$ invloed op die denke, houdings, ervarings, standpunte en toekomsverwagtings van lidmate het. Dit gaan nie in die eerste plek hier oor die waarheidsvraag of die verifikasie van sake nie, maar oor die omvang en boodskap van toekomsscenario's waarmee lidmate daagliks gekonfronteer word. Vir 'n sinvolle pastorale strategie rakende dié onderwerp, is 'n duidelike greep op hierdie sake van die grootste belang. Eers as ons die krisis van die lidmaat deeglik begryp, kan ons die lig van die Woord duidelik daarop laat val. Wat die omvang van die toekomsscenario's betref, kan drie breë kategorieë onderskei word:

\subsection{Sosiaal-ekonomiese scenario's}

Lidmate word daagliks met talle fasette van sosiaal-ekonomiese scenario's gekonfronteer. Ek noem slegs ' $n$ aantal fasette:

(i) Erich Leistner van die Afrika-Instituut wys onlangs daarop dat die tyd toe gemeen is dat Suid-Afrika 'n eerstewêreldland is, verby is. Hierdie visie was deel van ons denkraamwerk terwyl die apartheidsboot nog veilig gevaar het. Toe kon die blankes hulle nog as die ware Suid-Afrika sien, die swartes na tuislande uitskuif en vir hulle hier aan die suidpunt van Afrika 'n stukkie eerstewêreld bou - huise, geboue, paaie, gepaste infrastruktuur - en die swart probleem uit die oog (en uit die hart) verwyder. Hy wys daarop dat die tweede fase in die sewentiger jare aangebreek het toe daar na Suid-Afrika as ' $n$ land met twee komponente verwys is: 'n eerste- en 'n derdewêreldkomponent. Vandag praat ons van Suid-Afrika as 'n ontwikkelende land. Die volle realiteit hiervan sal ons binnekort vol in die gesig tref. Die uitstel daarvan bied geen oplossing nie - net so min as die wegskuif daarvan deur die aan die gang hou van uitgediende stelsels. (ii) Suid-Afrika bevind hom op ' $n$ broeiende kruitvat van rewolusie (baie beweer dat die rewolusie 'n paar jaar gelede reeds voluit begin het). Op die afgelope jaarvergadering van die Suid-Afrikaanse Akademie vir Wetenskap en Kuns is beweer dat $38 \%$ van die arbeidsmag van Suid-Afrika werkloos is. Dit is algemeen 
bekend dat werkloosheid en rewolusie hand aan hand gaan. (iii) Willie Breytenbach, hoogleraar in Afrika-studies aan die Universiteit van Stellenbosch, wys daarop dat Suid-Afrika uit en uit 'n derde-wêreldland is en dat blankes net nie die harde realiteite daarvan kan (of wil?) insien nie. Hy voorsien 'n agteruitgang in gesondheidsdienste vir die jare wat voorlê; baie groot geldelike bydraes vir ouers wat onderwys vir hul kinders verlang (daar word tans van owerheidsweë steeds R4 vir elke wit kind se onderrig bestee teenoor R1 vir elke anderkleurige kind). Hierdie verhouding sal waarskynlik dramaties verander. Swartes is nie meer hiermee gediend nie en om hul misnoeë te kenne te gee, is daar voortdurende stakings. Daar word bereken dat op enige gegewe skooldag in die jaar minstens 200000 leerlinge skole boikot. Ook die instandhouding van byvoorbeeld paaie, strate en die posdiens sal nie meer wees wat dit was nie. (iv) Die skrapping van die groepsgebiedewet sal die omvang van armoede en ellende, honger, roof en geweld op die voorstoepe van rustige blank Suid-Afrika laat verskyn. (v) In Februarie 1990 publiseer die Toronto Star 'n omvattende navorsingsverslag waarin dit aan die lig kom dat sanksies die gemiddelde wit Suit-Afrikaanse gesin die afgelope 4 jaar R50 000 aan onnodige prysstygings, verhoging van lewensduurte en verswakking van lewenspeil gekos het. (vi) Die tuimelende goudprys het blykbaar nog lank nie sy laagste draai gemaak nie. 'n Wêreldkonferensie oor goud einde Junie 1990 verwag 'n goudprys teen die middel van 1991 van tussen $\$ 190$ en $\$ 250$. Die impak hiervan op die uiters kwesbare Suid-Afrikaanse ekonomie sal katastrofaal wees. (Die inval van Irak in Koeweit het egter ' $n$ merkbare invloed op die stabilisering van die goudprys gehad). (vii) Selfs genl. Magnus Malan het onlangs beweer: wat verby is, is verby - ons durt nie enige tyd daarop mors nie. Die toekoms kom soos 'n sneltrein op ons af... (viii) In Julie 1990 maak die minister van Onderwys bekend dat slegs één enkele onderwysliggaam in die vooruitsig gestel word. (ix) Die gesprek oor die behoud van Afrikaans as amptelike taal word meestal in groot pessimisme gevoer. Floors van Jaarsveld beweer dat onder veilige beskutting die voortbestaan van ' $n$ Afrikaner-identiteit en -kultuur nooit ' $n$ ernstige probleem was nie. Met die ontmanteling van ' $n$ tradisionele Afrikanerstaat sal die Afrikaanse taal en kultuur moet klaarkom sonder die beskerming van ' $n$ eie staatsbestel. Die Afrikanerkultuur sal 'n subkultuur binne die gebied van ' $n$ meerderheidstaat wees met al die risiko's wat dit inhou. (x) In die onlangsverskene voorwoord tot Shell Suid-Afrika se jaarverslag wys die Uitvoerende Voorsitter, John Kilroe, daarop dat Swartmense vir meer as drie eeue lank met die geweld van onderdrukking, onhoudbare ongeregtigheid en die lelike las van diskriminasie moes saamleet. Die versoeking moet nou groot wees om hulle verbittering met ooreenstemmende geweld te wreek.

Dit is derhalwe vir baie ' $n$ verwarrende, ontstellende, vreesaanjaende en ongemaklike tyd waarin ons nou leef. Die nagmerrievraag word daarom al hoe brandender - gaan Suid-Afrika verder ontwikkel of in 'n chaos verval?

Met hierdie en baie ander sosiaal-ekonomiese toekomsmoontlikhede word ook ons lidmate daagliks gekonfronteer. Hierdie dinge krap mense om. Die liefdesgebod word immers Sondag na Sondag voorgehou. Is daar werklik ' $n$ goeie rede/verklaring vir alles of het ons die begrippe "Westerse beskawing" aan "Christelikheid" gelyk gestel? Het ons ' $n$ ideologiese muur gebou tussen ons eie beskerming en ons selfbehoud aan die een kant en die bybelse eis van die "bo-kleed" en die "onderkleed" aan die ander? Dit is van die etiese vrae wat in die huidige tyd lei tot besware of ongeduld - veral as die kerk/predikante (nie) die lig van die Woord op hierdie sake laat val (nie). 


\subsection{Polities-staatkundige scenario's}

Ook op polities-staatkundige vlak word lidmate daagliks met toekomsvooruitsigte gekonfronteer. Ek noem slegs enkeles:

Lidmate word daagliks gekonfronteer met onderhandelingspolitiek. ' $n$ LP skryf in Junie '90 dat dit nou algemeen aanvaar word dat die huidige grondwet met sy driekamerparlement binne die volgende paar jaar met iets anders vervang gaan word. Die doodvonnis oor die stelsel is gevel, maar die teregstelling lê nog voor. Hy skryf dat dit 'n LP in die parlement nogal 'n eienaardige gevoel van onsekerheid gee. Die werksaamhede van die afgelope sessie kan beskryt word as die administrasie van die apartheidsboedel... Hy beweer dat die land se politieke toekoms al meer buite die parlement bepaal word.

Rondom bewapening is daar talle verontrustende tekens: die diefstal van militêre wapentuig; die opkoms van "boerekommando's"; die onthulling van getuienis van 'n beplande "regse" staatsgreep; die erkenning van 'n regse groep dat hy verantwoordelik is vir die bomontploffing in Johannesburg in Julie 1990 waarin mense gedood en baie beseer is, én die belofte van meer aanvalle. Dit alles vertel die verhaal van mense wat tot die uiterste toe in verset kom. Van hierdie mense is dalk Ned. Geref. lidmate. Baie ander lidmate spreek hul openlike steun uit vir hierdie tipe optredes. Midde-in hierdie krisis staan die predikant en wonder oor sy gerigte pastorale optrede.

Al hoe meer klem val op groot byeenkomste waar getalle belangrik is. Een van die mees simboliese was die drie byeenkomste op 26 Mei 1990: met die terugkeer van die Staatspresident van sy buitelandse besoek: 'n groot heldeontvangs by die lughawe Jan Smuts; ' $n$ volksaamtrek van regses by die Voortrekkermonument en ' $n$ baie groot saamtrek van ANC-gesindes te Alexandra. Dr HC Marais van die RGN wys daarop dat dit in politiek oor mag gaan en in politieke stelsels is ondersteunersgetalle 'n belangrike vorm van mag. Belangegroeperinge word al hoe meer kritiek. Die kerk spring hierdie toutrekkery nie vry nie.

Onderhandeling met die "vyand", soos baie die ANC noem, is aan die orde van die dag. Daar word selfs openlik gepraat van 'n proses van medebesluitneming oor belangrike sake (wat in ' $n$ sekere sin reeds aan die gang is). Vir baie lidmate skep dit ' $n$ wesenlike probleem.

Die moontlike bestaan van moordbendes (Harms-kommissie van Ondersoek) is vir baie lidmate ' $n$ eties ontstellende saak.

In Junie (1990) stel Willem de Klerk, hoogleraar in Politieke Kommunikasiekunde van die RAU, die volgende verwagte politieke scenario vir die volgende 42 maande:

Die eerste stap was die suksesvolle ontmoeting tussen die regering en die ANC, die buitelandse toer van die Staatspresident en die pogings tot versoening tussen Inkatha en die ANC in Natal. Teen die middel van 1991 sal die agenda vir formele onderhandeling tussen die regering, die ANC en ander politieke partye waarskynlik vasgestel wees. Die derde stap sal die gevolg van die samesprekings wees: 'n sterk Swart verteenwoordiging in die kabinet (waarskynlik teen die begin van 1992). Die vierde stap sal die inwerkingstelling van die Nuwe Grondwet wees (gedurende 1993). Die vyfde stap sal 'n een-mens-een-stem-referendum wees (begin van 1994).

Bogenoemde is enkele van die polities-staatkundige toekomsvooruitsigte wat voorgehou word. Dit lei tot talle vrae waarvoor sinvolle, gerigte pastorale begeleiding te midde van hulle beswaardheid of ongeduld nodig is. 


\subsection{Kerklike scenario's}

Laastens is daar kerklike scenario's wat lei tot krisisbelewings by lidmate. Die Ned. Geref. Kerk beleef tans ' $n$ identiteitsoeke soos selde tevore in sy geskiedenis. In ' $n$ analise oor dié saak in Die Kerkbode (15 Junie 1990) het ek verwys na sake vanuit die kerk en sake buite die kerk wat tot hierdie identiteitsoeke gelei het:

\subsubsection{Sake vanuit die kerk}

Binne die kerk kan daar ten minste vier sake aangedui word wat gelei het tot die identiteitsvraag:

\subsubsection{Die belcid van apartheid}

Die eerste rede is die huidige verwarring en onsekerheid onder lidmate oor die teologiese interpretasie van die beleid van apartheid. By baie heers die persepsie dat daar voortdurende uitsprake téén apartheid is terwyl dit in die verlede geregverdig is (vgl. die omvang van die rimpelings wat die standpunt van die NG-afvaardiging te Rustenburg veroorsaak het) en dan volg weer sekere kwalifiserings van vorige standpunte ( $\mathrm{vgl}$. die Vereeniging-beraad). Terwyl baie lidmate met beswaarde gemoedere rondloop omdat die kerk "hom met politiek bemoei" (gewoonlik omdat dit teen die betrokke lidmate se persoonlike politieke voorkeure is), is ander weer toenemend teleurgestel in die kerk se onvermoë om die volle konsekwensies van die verwerping van apartheid in praktyk in verhouding met die Susterskerke deur te voer. 'n Derde groep (myns insiens die grootste getal lidmate) is skynbaar tevrede met die gegewene dat die kerk (bedoelende die kerkleiding) min of meer tred hou met die veranderings in die land en dienooreenkomstig die nodige geluide maak.

\subsubsection{Dic cenheid van dic kerk}

'n Tweede saak wat aanleiding gee tot die identiteitsvraag binne die kerk, is die gesprek rondom die eenheid van die kerk. Ons lidmate word voortdurend daarop gewys dat die kerk wel eenheid bely, maar as dit kom by die uitdrukking daarvan binne geloofsverband - in die N.G. Kerkfamilie of selfs tussen die drie Afrikaanse Susterskerke - dan word allerlei eksegetiese spronge gemaak om die verskeidenheid te "regverdig". Al meer lidmate vra die vraag: Neem die kerk sy belydenis oor die eenheid van die kerk werklik ernstig op?

\subsubsection{Afrikaanse Protestantse Kerk}

'n Derde identiteitsvraag binne die kerklike geledere raak die totstandkoming van die Afrikaanse Protestantse Kerk. Hoewel die persentasie lidmate wat die kerk verlaat 
het en na die APK oorgegaan het, gering is, is daar die toenemende kommer onder lidmate, predikante, kerkrade en sinodes, oor die (groot?) getal potensiële APK-lidmate in die kerklike geledere. Dit vraag ontstaan toenemend of die kerk nie meer die pas moet markeer om nie hierdie mense te verloor nie.

\subsubsection{Gemeentebou}

Die vierde identiteitsvraag wat die kerk van binne-uit beleef, is die vraag na die regte verstaan van die opbou van die kerk (gemeente). In die afgelope dekade het die kerk 'n bloeitydperk beleef wat getipeer kan word met die (tower-?) woord: gemeentebou. Die oplossing vir alle gemeentelike verval is gesoek in die implementering van gemeentebou. ' $n$ Verskeidenheid programme (van uiteenlopende gehalte) was (en is) in omloop met ewe uiteenlopende resultate. Sonder om hierop in te gaan, wil ek net een aspek uitlig wat die identiteitsvraag van die kerk betret. Hoewel byna alle gemeentebouprogramme op een of ander wyse klem lê op die twee kante van kerk-wees, naamlik die opbou- en uitboukarakter, is die opvallende dat die opbou-aspek feitlik deurgaans alle klem ontvang ten koste van die uitbou-aspek. Dit lei tot 'n ons-sindroom wat niks anders as ' $n$ heerlike geestelike warmbroeiery in 'n gemeente word nie terwyl die perspektief op die ware betekenis van kerk-wees uit die oog verloor word. Die groei van die kerk word gedegradeer tot 'n getalleaanwas deur middel van geboorte terwyl die opdrag in Matteus 28:19 in die gemeentelike lewe weinig tot sy reg kom en gekanaliseer word in 'n sendingtaak (en kerkstigting) "daar ver".

\subsubsection{Buite die kerk}

Ook van buite die kerk is daar faktore wat vrae oor die identiteit van die kerk na vore bring:

\subsubsection{Morele naprater}

Die eerste is die persepsie by ander kerke, instansies en waarnemers dat die Ned. Geref. Kerk eintlik niks anders as die morele naprater (en regverdiger) van die beleid van die regering van die dag is nie. Die indruk bestaan dat die kritiese distansie tussen regering en kerk vervaag het en dat dit in die kerk veral gaan oor die bevordering van die regte van die grootste gemene deler (van sy eie lidmate). "Veilige gevare" - soos die "kommunistiese, antichristlike, ANC" word met groot ywer bestry terwyl ander problematiese sake soos die oormatige beveiligingspogings en bewapening onder blankes wat gevoed word deur ' $n$ ideologie van sekurokrasie liefs nie aangespreek word nie. Die ideologieë van die twintigste $\theta e u$ in Suid-Afrika het byna klokslag vanuit kerklike kant ' $n$ verifierende en ondersteunende bondgenoot gevind.

$\mathrm{Na}$ die skeuring van die Nasionale Party in 1981 het daar ' $n$ ietwat groter distansie tussen die Ned. Geref. Kerk en die Nasionale Party gekom. Vir die eerste keer sedert (ten minste) 1948 was daar 'n sterk verdeelde stem aan twee kante binne die kerk. 
Ook van binne die kerk het daar 'n kritiese stem gekom oor die kerk se klaarblyklike noue band met die regering.

\subsubsection{Onvermoë oor kerkeenheid}

Die tweede faktor van buite die Ned. Geref. Kerk wat ernstige vrae oor die identiteit van die kerk na vore roep, is die (moedelose?) kritiese stemme vanuit die NGKerkfamilie. Die onvermoë van die Ned. Geref. Kerk om tot onvoorwaardelike skuldbelydenis én kerkeenheid te kom, word as ernstige struikelblokke beleef in die weg van aanvaarding dat die Ned. Geref. Kerk eerlik op soek is na 'n lewe vanuit die riglyne van die Woord van God.

\subsubsection{Toenemende sekularisme}

Die derde faktor wat 'n groot invloed uitoefen op die vraag na die identiteit van die kerk, is die toenemende sekular isme en die invloed daarvan op die kwaliteit van kerk-wees. As gevolg van die omvang van die kerk (getalsgewys) en die noue skakeling met owerheidsinstansies (bv. die SAUK), bestaan die persepsie by baie van die lidmate dat die moraliteit van die samelewing gelyk gestel kan word met die moraliteit van die kerk. Die styl van die samelewing word op subtiele wyse gelykgestel met die styl van die kerk. Die vraag na wie en wat die kerk eintlik is en wat die inhoud van die huidige pastorale praktyk moet wees, word al hoe brandender.

In hierdie analise van die wye omvang van die huidige en toekomsscenario's wat ons lidmate oorspoel, is dit duidelik waarom daar by lidmate ' $n$ (teologiese) ambivalensie aanwesig is: enersyds wil hulle duidelik hoor wat die Woord van God sê vir hulle daaglikse lewe as gelowiges in Suid-Afrika en andersyds wil hulle die profetiese Woord nie alte duidelik hoor nie aangesien dit dan na hulle sin te veel na politiekery begin klink.

Hoe moet leraars (pastors) dan optree? Moet ons veilig wees in ons vaaghede; moet ons by veilige sake soos algemene troos en bemoediging en "veilige" uitsprake bly soos: Onthou, God is in beheer? Die vraag na die verhouding tussen kerk en politiek moet pastoraal bekyk word alvorens die vraag na die pastorale sorg aan beswaardes en ongeduldiges sinvol aan die orde gestel kan word. Ons durf nie langer probeer om dit te omseil nie.

\section{Kerk (die pastor) en politiek}

Ek wil probeer om vanuit 'n nuwe invalshoek na die vraag te kyk. Geykte uitsprake soos: Die predikant mag sy eie partypolitieke keuse maak, maar dit nie verkondig nie; bediening van die Woord en politiek gaan nie saam nie; pasop vir die gevare van 'n "social gospel" ens. bied baie beperkte antwoorde op 'n veel gekompliseerder saak. Politiek is 'n heilige saak, soos alle ander aspekte van ons lewe. As dit by die politiek kom, is mense egter uiters gevoelig. Alhoewel dit op verbale vlak maklik klink asof mense politiek as iets "wêrelds" beskou, is dit opvallend dat - op ideologiese vlak - dit 
dikwels blyk dat politiek ' $n$ veel belangriker plek as "godsdiens" in mense se lewens inneem. Miskien is dit te verstaan: politiek het immers te maak met "praktiese" dinge soos werkverskaffing en welvaartverspreiding. Dit het ook te maak met vrede en oorlog. Dit kan gesinne se lot onomkeerbaar bepaal. Dit het te maak met salarisse en pryse, met lewensruimte en die gebrek daaraan. Dit het verder te make met onderwys en gemeenskapslewe, en met vryheid van godsdiensbeoefening, spraak en menseverhoudings. Kortom - dit het te make met die ganse eksistensie van die mens. Politiek is inderdaad ' $n$ heilige saak. Calvyn het, in sy verwysing na die Koninkryk van God gesê dat daar geen aspek van die lewe is waar God nie heers nie. Ons sou dit ook van die politiek kon sê.

As die politiek dan so belangrik is, dan besef ' $n$ mens onmiddellik dat geen verantwoordelike mens (ook nie die pastor nie!) hom van die politiek en die konsekwensies daarvan kan loswikkel nie. Hoe moet die pastor dan sy verhouding tot die politiek sien? Ek meen dat pastors in die verlede te veel gepoog het om nie kant te kies nie en hulleself in die proses so neutraal as moontlik, so vaag as moontlik of so in die middel as moontlik (die grootste gemene deler-beginsel) probeer posisioneer het. Die prinsipiële onhoudbaarheid van hierdie drie benaderings hoef nie eers beredeneer te word nie.

Die antwoord op die vraag na die verhouding tussen die pastor en politiek, is geleë in ' $n$ woord en daad lewenstyl gewortel in die navolging van Christus, soos verwoord deur Johannes die Doper: Hy moet meer word en ek minder. Dit is 'n styl van diakonia, die prysgee van die eie ek, eie belang, selfbehoud, die eie lewe. Dit behels die konkretisering van die eis om die tweede kilometer saam te loop, om nie net die bo-kleed nie, maar ook die onderkleed te gee, om skuld te bely as hy iets teen jou het, om barmhartigheid te bewys soos die Samaritaan - al kos dit ' $n$ besondere prys. Die antwoord is geleë, nie in politieke keuse na links, regs of die middel nie, maar in die verkondiging, pastorale konfrontasie en voorleef van die volle raad van God én die etiese konsekwensies daarvan. Dit is deel van die proses van heiligmaking waardeur ook die pastor voortdurend kom tot die ontdekking van die afgode in sy eie lewe. Eers as die pastor sy solidariteit met die gemeente ontdek as deel van die skare gelowiges wat moet luister na die Woord, sal dit hom vrywaar van die waan dat hy, omdat hy die bedienaar van die Woord is, die "regte" politieke keuse kan maak en die Woord dienooreenkomstig hanteer.

Vanuit sy eie insig van die Woord en die situasie makk die pastor sy politieke keuse. Sy taak is egter om homself (én sy keuses) voortdurend op die felste wyse voor die deursoekende lig van die Woord van God te plaas en dan die boodskap van dié lig (Woord) te verkondig, sodat sy gemeente (soos hyself) hulle lewens sal ondersoek, hulle sal bekeer en voortdurend sal reformeer.

In die lig hiervan kan ons dus nou 'n spesifiek-gerigle pastorale toespitsing op "beswaardes" en "ongeduldiges" maak.

\section{Pastorale sorg aan beswaardes}

Die sogenaamde "beswaarde" is die lidmaat wat 'n toenemende kommer en impasse met die Kerk beleef rakende nuwe rigtings wat ingeslaan word, en wat volgens sy oortuiging en persepsie nie korrek is nie. 


\subsection{Aard van die besware}

Die aard van die besware wat dikwels geopper word, is sake soos:

Die kerk se standpunt oor die beleid van apartheid. Die beswaarde se probleem is dat dit blyk dat die kerk die beleid van apartheid vir baie jare ondersteun het, bybels regverdig het én dienooreenkomstig verkondig het. Die nuwe gees en rigting sedert 1978 , soos veral weerspieël in Kerk en Samelewing, word bevraagteken.

Die band tussen Kerk en Owerheid word bevraagteken. Die vraag word gevra of dit nie juis die nuwe rigting van die owerheid is wat die kerk op nuwe bane geplaas het nie. Dit roep die vraag na vore of die kerk nie nou - met die eksplisitering van hierdie standpunte - met politiekery besig is nie?

Die aksent op die eenheid van die kerk lej tot groot kommer by "beswaardes". Daar word tans soveel klem gelê op die uitdrukking van die eenheid van die kerk (sigbaar oor kleur en moontlik ook taalgrense heen), dat die vraag gevra word of die kerk nie hiermee van een ideologie (apartheid - wat deur die meeste beswaardes nie as 'n ideologie gesien word nie) in 'n ander ideologie (die "ideologie van integrasie") verval nie?

\subsection{Aard van die simptome}

Die volgende sake is van die belangrikste simptome wat (in mindere of meerde mate) by beswaardes voorkom:

Daar word bale klem gelê op die handhawing van die eie (Afrikaner-) identiteit. Klem word gelê op die herkoms van die Afrikaner, sy volksplanting as Goddelike beskikkingsdaad en historiese bewaring van waaruit geredeneer word dat hy die eintlike handhawer van die Christendom in Suid-Afrika is. Klem word dikwels gelê op die kultuuropdrag van God aan die mens van waaruit gekonkludeer word op die ononderhandelbaarheid van "gegewenhede" soos kultuur en "beginsels" soos bepaalde lewenstandaarde. Simptomaties van die beswaardes is die aksent op die "feit" dat die kerk hom nie met politiek mag bemoei nie.

\subsection{Wat soek die beswaarde?}

In die lig van die aard van die besware en die aard van die simptome, kan die volgende sake uitgelig word as die "pastorale behoefte" van die beswaarde:

Die beswaarde soek by die pastor 'n regverdiging vir sy besware. Hy wil hê dat die pastor (en uiteindelik die kerk) hom gelyk sal gee. In die lig van die soeke na regverdiging, soek hy ook morele simpatie vir sy standpunte. Hy soek versekerings. Hy wil hê dat die pastor (kerkraad; kerk) hom die versekering sal gee dat die vrese en probleme wat hy voorsien nie bewaarheid sal word nie. Hy soek 'n uitlaatklep. Hy het behoefte aan 'n luisterende oor om sy eie vrese (dalk vir die eerste keer) bybels-moreel te probeer verwoord. Hy streef na 'n magsbasis. Hy wil die versekering ervaar dat, te midde van wankelende strukture, daar 'n magsbasis (die kerk) staande sal bly wat sy belange op die hoogste vlak (moreel-eties) sal beskerm. Hy soek beheer. Waar die hele samelewing (sosiologies gesproke) blyk te verkrummel, ervaar die mens 'n verlies 
van beheer. Die mens se natuurlike reaksie is om na subsisteme te gryp om hom in staat te stel om weer beheer te verkry ten einde te verhinder dat hy psigies verkrummel. Vir die gelowige word die kerk die simbolisering van die praesentia realis van God. Hierdie sisteem (waarvan die pastor die versinnebeelder is), moet hom help om beheer te verkry.

\subsection{Gerigte pastorale sorg}

Pastoraat aan beswaarde gaan nie oor antwoorde op elke gedetailleerde aspek van 'n beswaar nie - die Skrif is immers geen teksboek vir resepmatige optrede rakende enige pastorale probleem of vraag nie - maar oor die intense luister na die probleem, die deurgee van die eie worsteling en betrokkenheid by die saak (commitment), die saam gaan soek na die eise van die Woord, konfrontering met die eie antwoord rakende die eis van die Woord, biddende besluitneming en dan die saam soek na praktiese strategieë om opdrag te gee rakende die eis van die Woord.

Gerigte pastorale sorg behels dat daar op al drie bogenoemde vlakke sinvolle insette gegee sal moet word:

\subsubsection{Pastorant rakende dic aard van die besware}

Wat die aard van die besware betref, met name oor die beleid van apartheid, is dit noodsaaklik om in die prediking en pastoraat duidelik oor hierdie saak te wees. Dat die kerk in die verlede die saak verkeerd kon sien, is 'n feit. Dat die kerk die saak tans verkeerd kan sien, is ook moontlik. Wat egter belangriker is, is die vraag na die onvoorwaardelike gehoorsaamheid aan die Woord van God. Die pynlikheid maar noodsaaklikheid en omvang van die proses van selfkruisiging, minder word, mekaar se dienskneg word, 'n lewenstyl van magloosheid, die gesindheid van mekaar se voete te was, die lewenstyl van skuldbelydenis en vergiffenis (selfs as die naaste iets teen jou het), moet eksistensieel (vanuit die pastor se eie stryd hiermee) deurgegee word. Daar moet saam geworstel word en kwessies moet deurgepraat word om die eerste wankelende tree saam te gee om dit waarlik te doen.

Wat die vraag na die verhouding tussen kerk en owerheid betref, is dit een van die baie positiewe uitlopers van die politieke gebeure van 1981, naamlik dat daar 'n meer kritiese distansie tussen kerk en owerheid ontstaan het. Vanuit die radikaliteit van die Woord wat inspeel op die sondige lewensituasie, mag daar nooit 'n gemaklike bondgenootskap tussen kerk en owerheid wees nie. Die distansie tussen kerk en owerheid moet gehandhaaf bly en kan hoogstens solidêr-krities wees. Die styl van die kerk mag egter nooit dié van 'n maghebbende gespreksgenoot wees nie, maar moet altyd die van 'n andersoortige maglose wees.

Die beswaar oor die "gedwonge" eenheid van die kerk moet heenlei na die eis van die Woord in byvoorbeeld Johannes 17 . Vanuit die prinsipiële verstaan van die eenheid van die kerk kan daar (waarskynlik met veel groter deernis en minder subtiel ingeboude vooroordele) na die praktyk gekyk word om sinvolle en haalbare strategieë te vind waardeur daar meer en meer uitdrukking gegee kan word aan die eis van die Woord. 


\subsubsection{Pastorale sorg rakende dic simptome by die beswanrde}

Wat die aard van die simptome betref, is dit belangrik dat daar ' $n$ deeglike verstaan moet kom van die Bybelse mensbeeld (imago Dei - álle mense); die sondeval (alle mense) en die herstel van die beeld van God in Jesus Christus (almal wat Hom aangeneem het - ongeag of dit Griek of Jood is, geen voorrang - almal gelyk). Die saam deurworstel van die konsekwensies van die eis van die Woord rakende die nuwe verbondsgestalte - die kerk - as diakonale gestalte van magloosheid en selfopofferende liefde moet lei tot selfkonfrontering én koersaanpassing. In die pastorale sorg sal deegiik aandag gegee moet word aan die verhouding tussen die kultuuropdrag en die liefdesgebod. Die liefdesgebod (beide verhoudings - tot God en die naaste) mag nie gedegradeer word tot 'n ondergeskikte posisie aan dle kultuuropdrag nie. Vanuit die liefdesgebod moet die kultuuropdrag dienooreenkomstig dienstig gestel word.

\subsubsection{Pastorale sorg rakende dic behoftes van dic beswanrite}

Wat die behoeftes betref, is dit in die pastorale begeleiding nodig om die nuutheid en andersoortigheid van die nuwe mensheid in Jesus Christus uit te spel. Vanuit die ware verstaan van die nuwe lewensuitkyk - nie 'n aardse koninkryk nie, maar 'n hemelse moet die pastor as instrument in die hand van die Gees die beswaarde lei tot die ontdekking van die volheid van die lewe in Christus wat die loslaat van die eie (regverdigings, simpatie, mag en beheer) impliseer. Die nuwe mensheid behels 'n pneumatologies geïnspireerde proses van loslaat van ' $n$ antroposentriese lewenstyl en die oorgaan na die proses van 'n charismaties geïnspireerde lewenstyl.

Skematies kan die pastorale sorg aan die beswaarde soos volg voorgestel word:

\section{Beswaarde}

Aard

Apartheid

Kerk en Owerheid

Kerkeenheid
Aard
Gehoorsaamheid aan
Woord bo alies
Selfkruisiging
Dienskneggestalte
Magteloosheid lewensty!
Simptome

Afrikaneridentiteit

Handhawing van Christe-

like beskawing

Kultuurbehoud

Behoud van standaarde

Kerk nie polities

betrokke wees nie

\section{Pastorale sorg}

Simptome
Mens as Imago Dei
Radikaliteit van sondeval
Radikaliteit van herstel
in Christus Jesus
Ware kerk-wees

\author{
Behoeftes \\ Regverdiging \\ Morele \\ Versekerings \\ Uitlaatklep \\ Magsbasis \\ Beheer
}

Behoeftes

Andersoortigheid

van mens in Christus

Eskatologiese

Pneumatologiese

loslaat van eie 


\begin{tabular}{|c|c|c|}
\hline $\begin{array}{l}\text { Aard } \\
\text { Skuldbelydenis en } \\
\text { vergifnis } \\
\text { Kritiese distansie tussen } \\
\text { kerk en owerheid } \\
\text { Betekenis van Joh } 17 \\
\text { Bepaal rigting van } \\
\text { oplossings } \\
\text { Soek haalbare strategieë }\end{array}$ & $\begin{array}{l}\text { Simptome } \\
\text { Diakonale gestalte } \\
\text { Magloosheid } \\
\text { Verhouding tussen lief- } \\
\text { desgebod en kultuuropdrag }\end{array}$ & $\begin{array}{l}\text { Behoeftes } \\
\text { (Antroposentrisme) } \\
\text { Nuwe charismatiese } \\
\text { lewenstyl } \\
\text { g }\end{array}$ \\
\hline
\end{tabular}

\section{Pastorale sorg aan die ongeduldige}

Saam met die "beswaarde" lidmate in die kerk is daar ook ' $n$ groeiende getal "ongeduldiges." Die ongeduldige lidmaat is ' $n$ lidmaat wat ' $n$ toenemende impasse met die kerk beleef omdat die kerk volgens hom nie ver genoeg gaan om byvoorbeeld die volle konsekwensies van kerkbeleid (soos byvoorbeeld in Kerk en Samelewing uitgespel) deur te voer nie.

\subsection{Aard van die ongeduld}

Die aard van die kritiek teen die kerk wat van die kant van die ongeduldige geopper word, is sake soos die volgende:

Die kerk se standpunt oor die beleid van apartheid. Die ongeduldige se kritiek teen die kerk is dat dit lyk of die kerk hom nie werklik kan loswikkel van die ideologie van apartheid nie. Allerlei kwalifikasies word aan uitsprake geheg, soos dat die "negatiewe gevolge" van apartheid betreur word, skuld word bely "in soverre as wat" apartheid mense se lewens skade berokken het, ensovoorts. Vir die ongeduldige lyk dit asof die kerk net nie so ver kan kom om dit wat hy besef (apartheid is sonde) enkelvoudig, openlik en sonder voorbehoud te bely nie. In die Julie 1990- uitgawe van 'n glanstydskrif word 'n lang artikel gewy aan die onderwerp: NG Lidmate in opstand. Hierin word verwys na ontnugterde lidmate wat die kerk verlaat en by byvoorbeeld die N G Sendingkerk aansluit as gevolg van die volharding van die kerk by ' $n$ skewe vertolking van die Bybel om 'n gerieflikheids-ideologie in stand te hou. Daar word beweer dat die kerk die ware betekenis van Christelike naasteliefde en -diens verloor het.

Soos by die beswaarde, kry ons ook by die ongeduldige 'n bevraagtekening van die verhouding tussen kerk en owerheid. Die ongeduldige ervaar die noue band tussen kerk en owerheid negatief. Die feit dat so min van 'n kritiese distansie tussen die twee blyk, skep die indruk dat die kerk inderdaad die morele naprater (en regverdiger) van die nuutste beleidsrigtings van die regering is. Kerk en Samelewing word gesien as 'n dokument wat te laat verskyn het en te min om die lyf het. Predikante en lidmate beleef ' $n$ frustrasie rakende die profetiese stem van die kerk. So beweer Johannes Froneman dat die geskiedenis ' $n$ tragiese verhaal van verguising vertel oor (veral) predikante wat dit in die verlede al gewaag het om hul uit te spreek teen die system. Die vraag word al meer gevra of die ware profetiese stem van die kerk stil geword het.

Die ekumeniese beleid en koers van die kerk word bevraagteken. Ongeduldiges maak 
dikwels die opmerking dat die kerk net in ekumene belangstel as hy self die inisiatief geneem het en die hoofspreker is. Binne ons gepolariseerde samelewing word gemeen dat die kerk eerder ' $n$ sterker luisterende rol in die ekumeniese gesprek sal moet inneem.

Saam met die ekumeniese beleid word die onvermoë om tot uitdrukking te kom van die konsekwensies van ons geloofsbelydenis - met name die eenheid van die kerk ernstig bevraagteken. Die ongeduldige beskuldig die kerk van dubbelslagtigheid en huigelary omdat die kerkpraktyk en kerkbelydenis so ver van mekaar verwyder lê. Beyers Naudé beveel aan dat predikante en lidmate ' $n$ bond verontruste gereformeerdes moet vorm en 'n stem van verset en besorgdheid moet laat hoor. As dít nie gebeur nie, moet lidmate die tweede beste opsie uitoefen - om aan te sluit by die N G Sendingkerk en sodoende waarlik 'n Afrikaan te word.

Laastens word die kerk beskuldig van burokrasie. Die indruk bestaan vir baie ongeduldiges dat die kerk soveel klem op uitsprake "namens die kerk" plaas, dat die stem van individue stilgemaak word, as van min belang beskou word óf doodgeswyg word in byvoorbeeld die kerklike pers. Die ooraksentuering van "amptelikheid" en "amptelike standpunte" skep die gevoel van onmondigheid en miskenning by hierdie lidmate. Die kerkstruktuur word negatief as magsbasis beleef.

\subsection{Aard van die simptome}

In die lig van die voorafgaande manifesteer die ongeduld by lidmate in 'n verskeidenheid simptome:

Uitsprake van ongeduldiges spreek van frustrasie. Vanweë etlike bloutjies wat hierdie mense dikwels al met die kerkleiding geloop het, spreek hul optrede dikwels van frustrasie en selfs stereotipering van die kerk en kerkleiding. ' $n$ Tweede simptoom is 'n meewaarige houding teenoor medelidmate wat minder krities (ongeduldig) as hulle is. Die indruk word dikwels gewek dat hulle self reeds alles deurdink het en die antwoorde gevind het. Terwyl liefde teenoor anderkleurige gelowiges verkondig word, straal ongeduldiges dikwels weinig liefde, agting en respek jeens beswaardes uit. Uitsprake van eie kerkleiers word grootliks bevraagteken en gestereotipeer. Die kerk en veral die prediking word dikwels as a-polities gebrandmerk, vanweë die siening dat die kerk hom immers in ' $n$ hegemoniese situasie (d.w.s. in ' $n$ heersersposisie) bevind en dus rustig kan bid vir vrede en stabiliteit: sy lidmate het immers reeds alles wat verder nodig is! Die min aandag wat die plaaslike kerk aan sy evangeliserende, diakonale en sosiale taak in sy onmiddellike omgewing (vir alle mense) skenk, word genoem as ' $n$ duidelike bewys dat die kerk ideologies vasgevang is en die omvang van die eis van die Evangelieboodskap jammerlik verskraal.

\subsection{Wat soek die ongeduldige?}

Die innerlike "pastorale behoefte" van die ongeduldige kan soos volg uiteengesit word: Die ongeduldige het ' $n$ behoefte aan verandering. Hy wil graag sien dat gesindhede en strukture verander op pad na meer sigbare eenheid, en lidmate wat meer uitreik na medemense, medegelowiges (tans) buite die kerk. Die ongeduldige soek groter 
beweegruimte en meer klem op die priesteramp (mondigheid) van elke gelowige. Hy verlang na 'n kerk wat hom krities distansieeer van die negatiewe aspekte van sy tradisie. Hy soek ' $n$ groter dinamiese interaksie tussen geloofsbelydenis en geloofsdenke. Die konsekwensie van die geloofsbelydenis as samevatting van die volle evangelie wil hy sigbaar vergestalt sien in die praktiese lewe hier-en-nou. Hy soek 'n luisterende oor en 'n uitlaatklep: iemand wat kan luister en vanuit die Woord in 'n sinvolle koers saam met hom 'n pad in die praktyk van die lewe hier-en-nou stap.

\subsection{Gerigte pastorale sorg aan die ongeduldige}

Soos by die beswaarde gaan dit in gerigte pastorale sorg aan die ongeduldige nie oor die regte antwoorde of optrede nie. Aan die ander kant is ' $n$ baie spesifiek gerigte optrede van die grootste belang. Ook hier sal pastorale sorg op al drie bogenoemde vlakke moet inspeel.

\subsubsection{Pastorale sorg rakende die aard van dic ongeduld}

Wat die pastoraat aan die ongeduldige betref, kan grootliks gebruik gemaak word van die aksente wat reeds uiteengesit is onder 4.4.1 (Pastoraat aan beswaardes). Wat die kritiek op die kerk se standpunte oor apartheid en kerkeenheid betref, is dit belangrik om vir die lidmaat tot ' $n$ verstaan te bring van die feit dat die daad van Gehoorsaamheid aan die Woord deel van die groeiproses van die pad van heiligmaking is. Dit hou 'n prosesmatige aksie in. Alhoewel die kerk nie agter 'n tydskedule mag skuil nie (nog minder in 'n vertragingstaktiek) verander sake nie oornag nie. 'n Biddende gekyk na Bo vir leiding en aktiewe, sinvolle insette is van die allergrootste belang. Hiertoe moet die ongeduldige lidmate opgeroep word. Dit raak insette oor die verhouding tussen kerk en owerheid, apartheid, die eenheid van die kerk en ander aspekte rakende die uitdrukking in daadgetuienis van ons geloofsbelydenis.

Wat die kritiek oor die ekumeniese beleid en die kerkleiding betref, is dit noodsaaklik om die kritiek van vaaghede na spesifieke sake af te breek, deur foute uit te wys waar nodig (aan beide kante). Vanuit die erkenning van eie onvolmaaktheid moet saam met hierdie lidmaat gebuig word onder die gesag van die Woord. Voorts moet daar gebid word vir ons kerkleiding en waar die oortuiging steeds bestaan van sake wat nie reg hanteer word nie, moet dit in 'n gesindheid van pastorale ootmoed met die betrokkenes opgeneem word. Dit is dus nie 'n pastorale sorg wat gemik is op die oplegging van swye nie, maar op die deurtasting van standpunte en gesindhede in die lig van die Woord om vandaaruit sake (waar nodig) verder te voer.

\subsubsection{Pastorale sorg gerig op dic simptome by die ongeduldige.}

In die lig van die aspekte wat reeds by 4.4 .2 genoem is, is dit voorts in die pastorale optrede (wat die simptome by die ongeduldige betref) eerstens nodig om ' $n$ deeglike analise te maak van die aard, beweegredes en omvang van die voorkoms van frustrasie by die ongeduldige. Moontlike negatiewe persoonlike ervarings in dié ver- 
band moet ontmasker en deurgepraat word. Die gevaar van veralgemenings en stereotipering op grond van enkele persoonlike ervarings moet uitgewys word. Die oproep tot konsekwente naasteliefde (ook teenoor die beswaardes) moet tot gerigte skuldbelydenis en liefdesdiens lei. Die verhouding tussen kerk en politiek (soos vroeër breedweg uiteengesit) moet saam deurworstel word om te kom tot 'n sinvolle greep op die unieke (maar diepsnydende) invalshoek van die Woord in die politieke lewe.

Laastens moet die kritiek teen die gebrekkige uitleef van die evangeliserende, diakonale en sosiale taak van die kerk gelei word tot identifisering van gemeentelike strategieë en daadwerklike optrede in hierdie verband.

\subsubsection{Pastorale sorg rakende die behocftes van die ongeduldige}

Teenoor die gevaar by die beswaardes om weg te kyk van die hiernoumaals na die hiernamaals en sodoende die oë effens te sluit vir die sosiale onreg (waaraan die kerk slegs in baie beperkte mate iets doen) is die gevaar by ongeduldiges dat ' $n$ tipe idealistiese hemelse koninkryk op aarde gesoek word: 'n volledige gerealiseerde eskatologie. In die denkpatroon word daar dan soms te $\mathrm{min}$ van die radikaliteit van die sondeval gemaak en die mens as basies goed gesien word. Vanuit sy eie behoefte aan 'n geloofsbelydenis wat meer op praktiese vlak as geloofsdaad uitgeleef word, moet die lidmaat begelei word - nie tot 'n humanistiese lewenstyl nie, maar tot 'n lewenstyl wat radikaal Christelik is en vandaaruit die begrippe verandering (bekering), liefde en geregtigheid hanteer.

Skematies kan die pastorale sorg aan ongeduldiges soos volg voorgestel word:

\section{Ongeduldige}

Aard

Apartheid

Kerk en owerheid

Ekumeniese beleid

Kerkeenheid

Burokrasie
Simptome

Frustrasie

Meewaardige houding

Liefdeloosheid jeens

beswaardes

Kritiek teen kerkleiding

Stereotipering van

uitsprake

Kerk as a-polities

gebrandmerk

Plaaslike kerk te

onbetrokke in samelewing

Kerk in ideologiese greep
Behoeftes

Soeke na verandering

Beweegruimte

Mondigheid van elke

gelowige

Kritiese distansie oor

negatiewe uit tradisie

Meer dinamiese interaksie tussen

geloofsbelydenis en

gelooisdade

Uitlaatklep 


\section{Pastorale sorg}

Aard

Gehoorsaamheid as groeiproses

Biddende leiding

Aktiewe sinvolle

insette

Ondersoek gesindhede

Ekumeniese betrok-

kenheid en strategieë
Simptome

Analise van eie

frustrasies

Ontmasker

stereotiperings

Konsekwente naas-

te liefde

Begrip van verhouding tussen kerk en owerheid Identifiseer positiewe

strategieë - optrede/dade
Behoeftes

Hiernoumaals en

hiernamaals

Radikaliteit van

sondeval en verlossing

Radikaal Christelike

lewenstyl

* Bekering, liefde en geregtigheid

\section{Pastorale grondhouding}

Pastorale sorg aan beswaardes en ongeduldiges moet nie as sorg aan die twee uiterstes van die (polities-) kerklike spektrum gesien word as sou dit inhou dat die middelposisie die korrekte is nie. Pastorale sorg is (soos die geval met die hele bedieningspraktyk) nie ' $n$ bediening gerig op die verkryging van 'n groeiende grootste gemene deler nie. Daarom vereis pastorale sorg aan beswaardes en ongeduldiges elk 'n unieke bediening binne ' $n$ kerklike en sosio-politieke spanningsklimaat.

Van groot belang in hierdie gerigte pastoraat is die pastorale grondhouding. Vir die pastor is die regte grondhouding noodsaaklik om sinvolle pastorale rapport met die betrokkenes te vestig. Enige grondhouding wat vanuit persoonlike politieke voorkeure vertrek, sal slegs pastorale sorg aan een van die twee groepe moontlik maak. Sinvolle, gerigte pastorale sorg aan beswaardes en ongeduldiges is alleen moontlik vanuit ' $n$ voorleef, en voorhou van 'n konsekwente, ongekompromitteerde, Bybelse lewenstyl van die kerk (amptelik) en die pastor (as persoon).

Voorop in die pastorale grondhouding moet die onvoorwaardelike oorgawe aan die volle konsekwensies van die liefdesgebod staan. Vanuit die oorgawe aan en liefde tot God moet die pastorale deernis en liefde vir die naaste blyk. Hier word verwys na 'n naasteliefde wat die pastor juis dring om die lidmaat te begelei tot 'n (hernude, voortdurende) afsterwe van die sondige natuur (soos byvoorbeeld eiegeregtigheid) en 'n lewe vanuit die nuwe, herstelde verhouding tot God en die naaste.

Die pastorale grondhouding hou in dat die pastor 'n oog sal hê vir die volgende pastorale momente:

- Heling: in die verhouding tot God, die naaste en van sy eie impasse met sy sondige aard.

- Bystand: liefdevolle betrokkenheid wat lei tot die deurwerk van probleme en die "refraiming" van eie visies in die lig van die Woord.

- Begeleiding:om te kom tot eie strategiese aksie sodat die profetiese woord in 'n profetiese daad omgesit kan word.

- Versoening: as prakties-teologiese dieptepunt wat moet uitgroei tot 'n oorgegewe profetiese lewenstyl in 'n gebroke wêreld. 
- Uitsig: as eskatologiese gerigtheid op die wederkoms om steeds die regte visie op die aardse werklikheid te behou.

Pastorale sorg aan beswaardes en ongeduldiges vind plaas in 'n non-direktiewe styl, maar met 'n duidelike direktiewe inset deur die pastor vanuit die Woord. Die lidmaat moet (non-direktief), maar duidelik gerig en gelei word tot ontdekking van die volle eis van die Woord van God (direktief). In die tyd waarin die Ned. Geref. Kerk en sy lidmate hul tans bevind, staan die pastor midde in die branding. Om waarlik pastor te wees was op geen tydstip van die wêreldgeskiedenis 'n maklike taak nie. Die eise van die Woord van God moet deur hom bemiddel word aan lidmate in die kerk - Suid-Afrikaners met verwarde gemoedere - en so ook aan sy eie verwarde gemoed.

Die eis van die woord van God soos vervat in 2 Timoteus 4:1-5 moet daagliks prakties in hierdie spesifieke pastoraat gekonkretiseer word.

\section{NOTAS}

D Capps, 1989. Refraiming. A New Method in Pastoral Care, Minneapolis, Fortress Press. K Deddens, 1989. Een voortreffelijke taak. Profielschets van de pastor, Goes, Oosterbaan \& Le Cointre.

G Egan, 1986. The skilled helper. A Systematic Approach to Effective Helping, Pacific Grove, Brooks/Cole.

P McKay, 1989. A society in crisis today. In: Mason, J \& Rubenstein, J. Family Therapy in South Africa Today, Durban, 1989, 24-32.

EM Pattison, Pastor zijn in het sociaal systeem dat kerk heet, Haarlem, 1979..

W Scholte, Leven met het onvolkomene, Goes 1989.

$M$ te Velde, Gereformeerde gemeenteopbouw. Een eerste koersbepaling voor een nieuw theologisch vak. Barneveld 1989.

C Trimp, Klank en weerklank. Door prediking tot geloofservaring. Barneveld 1989.

$S$ van der Hoorn, Developing cultural sensitivity. In: Mason, J \& Rubenstein, J. Family Therapy in South Africa Today, Durban 1989, 32-37.

$H$ van der Linde, \& Van Hout. Oecumenisch pastoraat. Opbouw van oecumenische gemeenschap tussen plaatselijke kerken, Kampen, s.a.

WR van der Zee, Wie heeft daar woorden voor? Een pastorale over lijdende mensen en een leidende god, 's-Gravenhage 1983.

HJ Veldkamp, Pastoraat als gelijkenis. De gelijkenis als model voor pastoraal handelen, Kampen 1988.

WH Velema, Politieke prediking. Kampen 1972.

WH Velema, Ethische vragen in prediking en pastoraat, Kampen 1989.

WH Velema, (red.) Delen in het heil. Over de toeëigening van het heil in Christus, Kampen 1989. 